位; 珪酸 20\% 位の8のが多い。か」る低品位鐉石を如何にして多 量に開發し,如何にして最子能率よく製鍊し, 如何にして珪素分の多 いその製品を製銅原料に供するかといふ事が目前の大問題である。

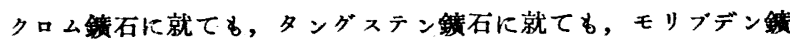

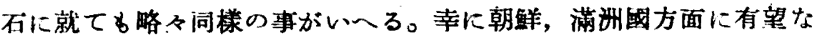
開拓が期待されてるる。

最近漸く問題になつてるるヴァナヂウム並にジルンニウムに閵し ても深甚な對策が必要であるっヴァナデウムは既に國內でる一部開 發されてるるが，熱河方面に太いに期待される。ジルコニウムは要 澌待されてるる。

即ち鐵合金工業に關しては電力の確保と，低品位資源の開發が現 下の問題であり，本工業は次第に外地一外地一と發展すべす機運に ありと考へられる。

\section{脫 酸 劑}

鐵合金以外の脫酸劑として今日用ひられてるろのは珪化カルシウ ム (Ca 30\%, Si 60\%) である。これる最近漸く望用されると到つ たるので, その生座量は僅少である。しかし將來は特殊の脫酸劑か 現れ，盛んK使用さるに到ると思はれる。例人ばアルミ・チタンの 如き既に资用されんとしてるる。マンガン・カルシウム，アルミ・カ ルシウム等す既に研究的に製造されてるる。とれ等は主として電氣 䜋で生座される。製銅工業の發達に件つて脆酸劑工業る技術的に注 目されるのである。

\section{總 括}

以上各種の製鋼原料を通筧するに，その品質は何れる使用に堪え 得る程度であり, 又種類別的にる不足はない。本滑運轉には不充分
の所るあるが，製造技衔は概して進步してふる。今日より研究を装 する部分は大局的に見て少い。さされば現下の問題は如何にしててれ を多基生库し，製鋼事業の泪滑な操業を期するかといふ事にある。

製銅の一分野としてトーマス法が再び泩目され，てれが佰設を急 いでるる。これは多量生厍に適當した方法であるが，てれのみを以 て製銅多量生遮を行ふわけには行かない。トーマス鋼には自ら限度 がある。本㠊製銅に依る多量生座が依然極めて必要なことであり。 これには普通級屑鐵の代用となるべき原料が必慗なのである。これ

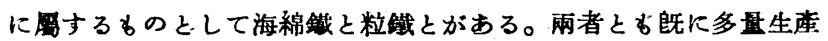
に着手して居り, 着々進行してるろが, 設借と资材と時間を多く装

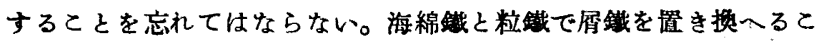
とは筫に並大抵ではない。こ〉に重點主義の必要があり, 是が非で るてれを斷行して難關を切拔けなければならないのである。

特殊な高級鎙を作る原鐵は例人ば純度であり，素銅である。これ 等は多量生産をそれ程必要とするるのでないから，順詶に進行する ஆのと思はれる。今日各所でこの製造が盛んである。嵪級鋼の原料 に最る道した原鐵を, 最る能來よく製造することが國策的であり， この點に注意が必要である。

次は凟源確保と低品位銈石の開發利用である。現狀を以てすれば 殆ぞ總ての重金盛飞對して，との原則を適用しなければならない。 低品位鉷石の利用は郎ち精密治金である。精密治金は化學を最も巧 妙に應用して有用减分を殘らず捕集分別することを特徽とする。二 の方面に治金は進まなければならない場合にある。ニッケれ治金， コバルト治金, ヴァナギウム治金, ジルコンウム治金, タンタれ治 金，ベリリウム治金等その例である。

このやらに我國の製銅原料工業界には緊急重哭問題が澤山ある。 これを解決してはじめて製龬工業が㴻滑に發達する。

\title{
“均一”氣體觸媒反 應
}

武藏高等學校・根津化學研究所

“均一”解媒反應の特徵は解㛽物質が氣相又は液相中に分子的に 分散されを狀態に於て存在することである。この均一解媒反應は從 來主として液相に於てその望例…多くの酸及び 監基の 觸媒反應 はその顥著な例である…方知られてるるのであるが, 近時に至つ て氣相中に於てる，能媒物質自體が一つの氣體である場合にこれが 鿓現されることが知られた。尤子其の意味に於て“均一”な氣體

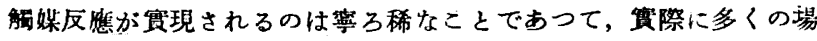
合に氣體反應の機構を仔緗に檢へてみると，その反應が決して均一 の氣相空間に於て行はれてみず, 却て反應容器の器壁又は反應空間 中に浮游する微粒の液滴或は堙塵等の表面に於て行はれてるるため に，貫は“不均一”であるとい子場合が少くないのである。しか し近來ドィッの. Bodenstein, イギリスの Hinshelwood, ソヴ.ィエ 一ト㖒邦の Semenoff 等を中心とする研究に於て畺に“均一”。 氣體触媒反應の幾つかの赛例が發見された。以下に於てその二, 三

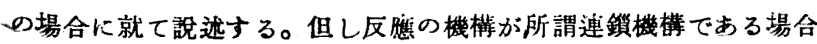
は問題が演讯であるから此處には解れないことにする。なほ又こ」 下所謂解媒とは一般にそれが少量存在することに依て或與一られた

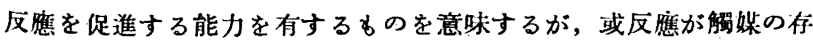
在の下に於て行はれる場合と; それが触媒なしに行はれる場合とに 於て，その反應の機構は必ずしる同一ではない。

\section{1. ハロケンを觸媒とする氣體反應}

Hinshelwood 及び共原研焭者は氣相中に於ける種々の有機化合

\section{王䖵・文一}

物の一分子的分解反應に關する詳細な研究を遂行したのであるが， これと件つて彼等は“均一”氣相分解反雇が他の氣體物啠（特に $\mathrm{I}_{2}$ ) の存在によつて著しく促進されるといふ事筫を證明した。多く のエーテル(メチル・ェチルー, ギェチル -, イソプロピル・メチルー, ヂイソプロピル-等) の分解の反應速度は $10 \mathrm{~mm} の \mathrm{I}_{2}$ の加入によ つて $10^{2} \sim 10^{5}$ 倍に㫮大される*。多くのアルデヒド(フォルムア ルデヒドは例外) の分解む亦 $\mathrm{I}_{2}$ に依て促進される。例人ばアセト アルデヒド及びプロピオンアュデヒドの分解反應速度は $10 \mathrm{~mm}$

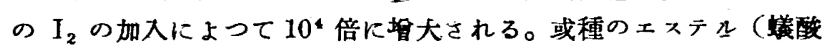
メチル, 醋酸メチル) 及びアミン(ヂェチれ-, ヂメチルー, トリメ チハー,トリエチルー）同栐の行動を示す。但しアルデヒド改びメ

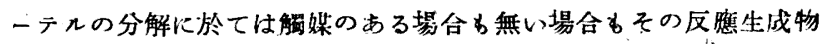
は同じであるが, 他の反應に於ては兩者の場合の反應生成物に多少 の相違が認められる。

一例一ばメチル・ェチル・エーテルの分解は $450 〜 556^{\circ} \mathrm{C}$ 飞於て研先 されたが次の如く行はれる：

$$
\begin{aligned}
& \mathrm{CH}_{3} \cdot \mathrm{O} \cdot \mathrm{CHCH}_{3} \rightarrow \mathrm{CH}_{4}+\mathrm{CH}_{3} \mathrm{CHO} \\
& \uparrow-\stackrel{1}{\mathrm{H}} \quad \stackrel{1}{\mathrm{CH}_{4}}+\mathrm{CO}
\end{aligned}
$$

反鹪速度江次式に從了:

$$
v=l:\left[\mathrm{I}_{2}\right][x-\text { テル }]
$$

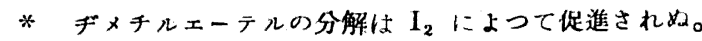


$\mathrm{I}_{2}$ の遢力 $6.7 \mathrm{mmHg}$ に對して $500^{\mathrm{C}} \mathrm{C}$ に於て $k=5.36 \cdot 10^{-3} \mathrm{sec}^{-1}$, 活性化熱は $38, \mathrm{C} 00 \mathrm{cal}$, 從て $k$ は次式に依て示される。 $k=3.7 \cdot 10^{8} e^{-38,300 / R T} \sec ^{-1}$

惯際に分解するエーテル分子の數を氣體論から計算される $\mathrm{I}_{2}$ 及 びェーテル分子間の有效衝笑數と此較してみると, 前者は後者の約 7 倍に達する。な法この反雔が觸媒無しに行は札る場合の活性化熱 は $47,000 \mathrm{cal}$ である。

アセトアルデヒドの分解は次の如く行はれる：<smiles>CC(=O)C1CC1</smiles>

この場合す反應速度は $v=k\left[\mathrm{I}_{2}\right][$ アルデヒド]によつて表され， $423.5^{\circ} \mathrm{C}$ 及び $\mathrm{I}_{2}=10 \mathrm{mmHg}$ に於て $k=2.2 \cdot 10^{-2} \mathrm{sec}^{-1}$ である。活

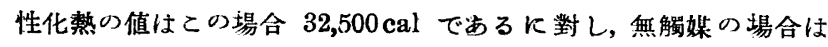
$45,500 \mathrm{cal}$ である。又赛際に分解するアルデヒド分子數と, 計算さ れる有效衝笑數との比は 0.1 である。

嬟酸×チルは $451^{\circ} \mathrm{C}$ K於て, $I_{2}$ によつて次の如く促進的に分解 される:

$$
\begin{aligned}
\mathrm{H} \cdot \mathrm{CO} \cdot \mathrm{OCH}_{3} \stackrel{29 \%}{\longrightarrow} \mathrm{CH}_{4}+\mathrm{CO}_{2} \\
\longrightarrow
\end{aligned}
$$

てれ等の反應に於て觸媟として作用するものが分子狀の沃素であ ることは，反應通度の表式に依て確認される。又貸際に分解する反 . 雔物質の分子數が, 反應物質分子々触媒分子との二分子反㮣として 計算した數と大體に於て一致するといふ事實から，我々はての觸媒

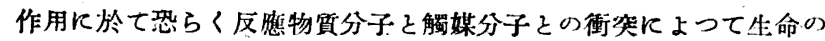
短…種の錯化合物が生成し, このものが再び解體して反應生成物 を生ずると同時に，触媒分子を再生させるであららと推定する。

ところで上記の諸反應に於てみられるゃ 问時に行はれるのは反應物質分子内の $\mathbf{H}$-原子の移動であるが, こ れ务如何なる機構に於て行はれるのであるか，こ〉に考察すべき問 題がある。乙の點に關して考へられる事は先づ反應する分子の電氣 的隻極子としての特性であるるしかもェーテル，ェステル，アミン 等に於てその雙極子能率は分子内に於て分解を起すへき結合部分に 配㯰されてるる。これに對して解媒として作用する $\mathrm{I}_{2}$-分子い電氣 的性質 $\left(I_{2}\right.$ の分子㐿折の值は 32$)$ が問題となる。乙の分極性の解 媒分子が反應物質の雙極子分子に接近するとき，觸媒分子内に感崤 的に雙極子を形成する。從ててつに雙極子的䊅合體が形成される。 そして若しての街突錯化合物に於て相結合する二分子の相互的配置 が適當に行はれるならば，触媒分子の有する振動エネルギーが反隼 分子の中に讓與されるであら5。かやらな機作の結果として與へら れた分解反應の活性化ェネルギーが低下し, 從て反應速度が搵大寸

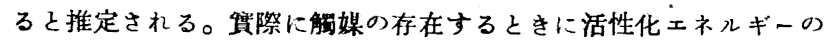
低下することは上記の例に於て示した通りである。

なほ文複雜な分子を榞起して活性狀態にもたらす際にはその分子 に固有の振動の自由度の数加問題となる。例人ばェーテル分子の分 解が觸媒なしに行はれるときは, その分子に於て少くるも 13 個の 自由度汃缕起されねばならない。しかるに $I_{2}$-分子が存在するとき は唯 1 個の自由度を檒起すれば足りる。この事は反應物質分子に對 する触媒の作用加甚だ特殊的であつて, 反㮣物質分子内の或特定の 部分が選擇的に影響さるべき事を暗示する。

エーテル或はアルデヒドの分解に對して次のやらな反應機作:

1. $\left(\mathrm{C}_{2} \mathrm{H}_{5}\right)_{2} \mathrm{O}+\mathrm{I}_{2}=\mathrm{C}_{2} \mathrm{H}_{5} \mathrm{I}+\mathrm{HI}+\mathrm{CH}_{3} \mathrm{CHO}$

2. $\mathrm{CH}_{3} \mathrm{CHO}+\mathrm{I}_{2}=\mathrm{CH}_{3} \mathrm{I}+\mathrm{HI}+\mathrm{CO}$

3. $\mathrm{CH}_{3} \mathrm{I}+\mathrm{HI}=\mathrm{CH}_{4}+\mathrm{I}_{2}$.
も想定されてるるが，ての見解は米だ一般的に磼認されてるないゃ らである。

$\mathrm{Br}_{2}$-分子及び $\mathrm{Cl}_{2}$-分子Kよつて促進される有機化合物の分解反 應の筷例は $\mathrm{I}_{2}$-分子の場合に比して遥に少い。しかしアセトアルデ 七ドの分解は $300^{\circ} \mathrm{C}$ 以上に於て $\mathrm{Br}_{2}$ 依て促進される。又ヂエ チル・エーテルの分解は $\mathrm{Cl}_{2}$ 倠て促進される。トリメチル・ア ミン及びメチル・エチル・ケトンの分解は $\mathrm{Cl}_{2}$ Kよつて僅に促進 され，オゾンの分解は $\mathrm{Cl}_{2}$ 或は $\mathrm{Br}_{2}$ に依てかなり著しく促進され ろ。

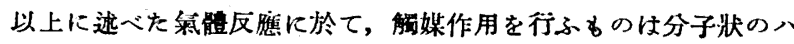
ロゲンであつたが，原子狀のハロゲシが均一氣體反應の触媒として 作用する場合がある。その顯著な一例は $\mathrm{N}_{2} \mathrm{O}$ が分解して $\mathrm{O}_{2}$ 及び $\mathrm{N}_{2}$ を生ずる反應である。この場合反應臬度は上述の有機化合物の 分解の場合のや5Kハロゲン分子の原力に比例せず, 管るこの本方 根に比例する。郎ちこの際にはハロゲン分子と熱的平衡に於て存す る所のハロゲン原子が触媒作用を行ふすのを推定される。Volmer 及び Bogdanによれば， $\mathrm{N}_{2} \mathrm{O}$ の分解は水銀蒸氣に低て子促進され ることが確められてるるが，乙の場合の解媒はもとより一原子的の 楊體であり，その反應速度は $\mathrm{Hg}$-蒸氣の分避に比例して塯すので ある。

クロラルの分解が Hinshelwood 等によつて 353 412 ${ }^{\circ} \mathrm{C}$ に於て 研究されたが、この際

$$
v=k\left[\mathrm{CCl}_{3} \mathrm{CHO}\right]\left[\mathrm{I}_{2}\right]^{\frac{1}{2}}
$$

が戌立し，觸㨫として作用するものは I原子であることが知られ た。そしてその反應機作は次の如く推定される：

$$
\begin{aligned}
\mathrm{I}_{2} & \rightleftarrows 2 \mathrm{I} \quad(\text { 熱的本得) } \\
\mathrm{I}+\mathrm{CCl}_{3} \cdot \mathrm{CHO} & =\mathrm{CCl}_{3}+\mathrm{CO}+\mathrm{HI} \\
\mathrm{CCl}_{3}+\mathrm{HI} & =\mathrm{CHCl}_{3}+\mathrm{I}
\end{aligned}
$$

但しクロロンォルムは高溫に於て更に分解する。

\section{2. パラ，オルト水素の轉移反應}

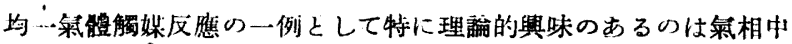
に於ける $p$-文び $a$-水素の轉移反應である。よく知られてるるゃら に $\mathrm{H}_{\mathbf{2}}$-分子に於てはこれを構成する 2 個の $\mathrm{H}$-原子の核能率の“ “ ピン”が五に反本行的な場合と本行的な場合とに憵じて夫々 $p$-水 素及び o-水素の二継態が存在する。そしててれ等は自由の $\mathrm{H}$-原子 の作用によつて次の如く轉移する。

$$
\underset{\uparrow}{-\mathrm{H}_{2}+\mathrm{H}} \stackrel{l_{1}}{\stackrel{k_{2}}{\rightleftarrows}} \underset{\uparrow}{\mathrm{H}}+0-\mathrm{H}_{2}
$$

即ちこの場合 $p$-水素分子中の水素原子之遊離の水素原子との間 に入れがが行はれる。贯際に $600^{\circ} \mathrm{C}$ 附近ともなれば, 熱解離に よつて相當量の $\mathrm{H}$-原子が $\mathrm{H}_{2}$-分子と平衡を保つて存在するが故 に，上記の反應はかなりの速度を以て進行するゃらになる。この場 合轉移速度は次式に依て示される：

$$
-\frac{d\left[p-\mathrm{H}_{2}\right]}{d t}=k_{1}[\mathrm{H}]\left[x-\mathrm{H}_{2}\right]-k_{2}[\mathrm{H}]\left[0-\mathrm{H}_{2}\right]
$$

今 $\left[\mathrm{H}_{2}\right]$ の全涉度ひ中 $x$ 部分が $\left[p-\mathrm{H}_{2}\right]$ であるとすれば，

$$
-\frac{d\left[p-\mathbf{H}_{2}\right]}{d t}=-\frac{d x\left[\mathbf{H}_{2}\right]}{d t}=k_{1}[\mathrm{H}] x\left[\mathrm{H}_{2}\right]-k_{2}[\mathbf{H}](1-x)\left[\mathbf{H}_{2}\right]
$$

栍分によって

$$
\left(x_{t}-\frac{k_{2}}{k_{1}+k_{2}}\right)=\left(x_{0}-\frac{k_{2}}{k_{1}+k_{2}}\right) e^{-t(H)\left(k_{1}+k_{2}\right)}
$$


但し $x_{0}$ は $t=0$ に於ける $p-\mathrm{H}_{2}$ の量, $x_{t}$ は $t$ に於ける $p-\mathrm{H}_{2}$ の量である。又 $k_{1} / k_{2}$ は本衡に於ける $c-\mathrm{H}_{2}$ と $p-\mathrm{H}_{2}$ との比であ 亏から, $k_{2} /\left(k_{1}+k_{2}\right)$ は本衡に於ける $p-\mathrm{H}_{2}$ の比較的量を示してる 万。從て

$$
-\left(x_{t}-\frac{k_{2}}{k_{1}+k_{2}}\right)=u_{t}, \quad\left(x_{0}-\frac{k_{2}}{k_{1}+k_{2}}\right)=u_{0}
$$

と置けば $u_{t}$ 及び $u_{0}$ は夫ヶ $t$ 及び $t=0$ に於ける平衡婊度に對す る $\boldsymbol{F}-\mathrm{H}_{2}$ の週剩量（モル分率で示す）を意味する。寒際に上の關 保は溫度 $600 \sim 900^{\circ} \mathrm{C}$, 厭力 $50 \sim 760 \mathrm{mmHg}$ に於て成立する事が

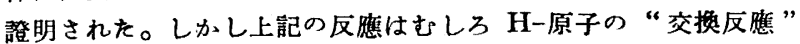
ともいふへきものでこれを触媒反隹といふのは當らない。

ところで，Farkas 及び Sachsse は低溫に於て遊離の H-原子 の存在しない所に於て, $p$ 一小素の轉移が分子狀の酸素の影㢣に依て 促進される事寒を發見した。しかもこの際の反應は次の如く行はれ る:

$$
p-\mathrm{H}_{2}+\mathrm{O}_{2} \underset{k_{2}}{\stackrel{k_{1}}{\rightleftarrows}} o=\mathrm{H}_{2}+\mathrm{O}_{2}
$$

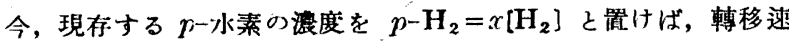
度は次式に從ふ。

$$
-\frac{d x\left[\mathrm{H}_{2}\right]}{\cdot d t}=k_{1} x\left[\mathrm{H}_{2}\right]\left[\mathrm{O}_{2}\right]-k_{2}(1-x)\left[\mathrm{H}_{2}\right]\left[\mathrm{O}_{2}\right]
$$

從て穔分によって前記の熱轉移の場合と類似の關保を得る。

$$
\left(x_{1}-\frac{k_{2}}{k_{1}+k_{2}}\right)=\left(x_{0}-\frac{k_{2}}{k_{1}+k_{2}}\right) e^{-t\left\{0_{2}\right)\left(k_{1}+k_{2}\right)}
$$

或は

$$
u_{t}=u_{0} e^{-t\left(0_{2}\right)\left(k_{1}+k_{2}\right)}
$$

似し測定の間 $\mathrm{O}_{2}$ の婊度は不變に保たれる故に水素に關しては 1 次 反應と見做してよい。

ての反應は完全に“均一”であり，しかもとの際の酸素分子の 作用は触媒的である。そしてこの触䍀作用の原因は $\mathrm{O}_{2}$-分子が常 磁性であるとい子ととに䲞せられる。

原子物理學の教へる所によれば, 電子に“スピン”があり, 從 て磁氣能率が存する。しかし偶數個の電子を所有する體系に於て は,その中の電子のスピンは 1 對宛の組合せによつて相互に對挡す るために，全體として磁氣能率を殘さず，その體系は反磁性となる。 これに對して奇數個の電子を有する體系に於ては，1 對宛の組合せ が行はれてる最後に 1 個の瓜立電子が残るために磁氣能率が存し, 己の體系は常磁性となる。例一ば $\mathrm{NO}, \mathrm{NO}_{2}, \mathrm{ClO}_{2}$ の如き分子, ア ルカリ金屬原子, 八ロゲン原子及び一般に遊離の基はかっる意味に 於て常磁性を有する。尤も $\mathrm{O}_{2}$-分子は偶數個の䉓子を有するに拘 らずな酒磁性である。これはこの分子中に於て互にスピンを對償 しない 2 個の電子が存在するによる。

さてかやらな常磁性物質は互に電子のスピンを领和し合ふ事に依 て他の物貿々反應する特性を有する。遊離基卜リフェニルメチルが $\mathrm{O}_{2}$ 一分子と結合してトリフェニルメチルの過酸化物を作るのはその 典型的な一例である。

$$
2\left(\mathrm{C}_{6} \mathrm{H}_{5}\right)_{3}-\mathrm{C}-+\mathrm{O}_{2} \rightarrow\left(\mathrm{C}_{6} \mathrm{H}_{5}\right)-\mathrm{C}-\mathrm{O}-\mathrm{O}-\mathrm{C}-\left(\mathrm{C}_{6} \mathrm{H}_{6}\right)_{3}
$$

しか子此處に生成する過酸化物は反磁性的である。

更に又常磁性の分子又は原子はそれがその周圍に分子的大きさの 不均一の磁場を有する事飞依て, てれ等が或種の化學反應に於て触 媒的效果を具現するてとがある。p-水素轉移に於ける $\mathrm{O}_{2}$-分子の 作用はまさにその影著な例である。乙の際恐らく $p$-水素の分子は その街突對手である $\mathrm{O}_{2}$-分子に對して無限にはやく或距離の所まで 接近し, 若干時間そてに滞在して後再び無限に速に飛び去る。ての 街突の操作の間に於て常磁性分子の有する分子的不均一の磁場が 2

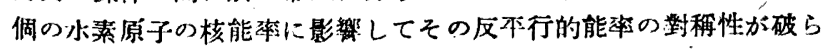

れ，同時に原子の組換一が行はれるものと推定される。ての場合の

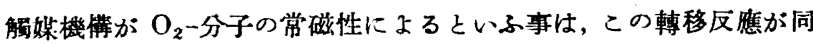
じく常磁性である所の $\mathrm{NO}$-或は $\mathrm{NO}_{2}$-分子によってる同樣に促進 されるといふ事惯に依て衰書される。

常磁性分子の街突によるp-水素轉移反應の理論はWigner, Kalckar 及び Teller によつて提出された。此處にこの理論の詳䧃を 記すととを避けるが，その結果は大體に於てよく惯驗事赛と調和す る。理論的計算の結果によれば, この際の反礁速度は第にに衛突分 子 $\left(\mathrm{O}_{2}, \mathrm{NO}, \mathrm{NO}_{2}\right)$ の磁氣能本 $\mu$, 第 2 に衝突に際して分子が相 に接近しらる極限の距離 $a$, 第 3 に街突の時間 $t$ によつて支配され る。そして結局 $20^{\circ} \mathrm{C}$ に於ける反應速度に對して次式が導かれた：

$$
k=3.9 \cdot 10^{-31} \cdot \mu^{2} / a^{4}
$$

上式の數字部分には普遍常數の外に水素分子に固有の數量 (プロ トン能率等）が含まれる。との計算結果は上く赛驗結果と一致す る，從て又との式は反應速度の測定によつて逆に觸䍀分子の磁氣能

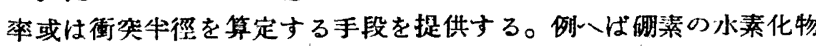
$\mathrm{B}_{2} \mathrm{H}_{6}$ は $\mathrm{O}_{2}$-分子飞闹數の電子を有するのであるが，とれる亦 $\mathrm{O}_{2}$ と同樣に常磁性であるかどらかは興味ある開題である。Farkas 及 び Sachsse によれば $\mathrm{B}_{2} \mathrm{H}_{6}$ は明かに $p$-水素轉移を促進する能力 のない事が確められた。從て $\mathrm{B}_{2} \mathrm{H}_{6}$ は却て反碳性であると結論さ。 れた。この知見は $\mathrm{B}_{2} \mathrm{H}_{6}$ の構造といふ厄介な問題に對して一つの 重要な知見を與一るものである。

\section{3. エチレン化合物のシス・トランス轉位}

エチレン化合物のシス・トランス轉位反應が或種の觸媒の存在の 下に於て行はれるといふ事赛が知られてるる。例人ばマレイン酸エ ステルよりフマル酸ェステルへの轉位はェーテル中に於てガリウム 粉と共に加熱する事に依て促進せられ，シス・スチルベンよりトラ ンズ・スチル゙ヘンへの轉位:<smiles>CCCCCCCCCCCC</smiles>

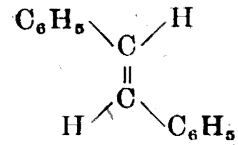

は金屬ナトリウムによつて促進される。 このやらな場合如何なる機作儿依て反應が行はれるかは興味ある 問題であるが，これに就て R. Kuhn は頗る暗示的な見解を發表し た。彼によれば一般に常磁性物矮がエチレン化合物のシス・トラン

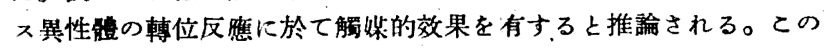
推論は大體次の如くである。

エチレン化合物は一般に正常の狀態に於て
(I) $\ddot{\dot{C}} \vdots \dot{\mathrm{C}}$.
(II) $\dot{\vec{C}} \vdots \dot{\mathrm{C}} \cdot$
(111) $: \underset{K}{\ddot{\mathrm{C}}:} \ddot{\mathrm{C}}:$

（I）のやらな電子配置を有してるろがとつにそのスピンが對貲さ れてるない1個の電子を有するとてろの常磁性门解媒 $(K)$ が街笑 によつて接近するとさは, 二重結合に與つてるる笔子の中の 1 個が 正常の狀態からはずれて (II) に示すやらな㷮起狀態儿移行する。

\begin{tabular}{|c|c|c|}
\hline タ ン結合 & $\mathrm{C}: \mathrm{C}$ & $1.52 \AA$ \\
\hline ヘンンゾール結合 & $\mathbf{C}: \mathbf{C}$ & $1.44 "$ \\
\hline エチレン結合 & $\mathrm{C}:: \mathrm{C}$ & $1.35 "$ \\
\hline アセチレン結合 & $\mathbf{C} \vdots \vdots \mathbf{C}$ & $1.20 "$ \\
\hline
\end{tabular}
そして同時に $K$ はその1個の電子を以て一方の炭素原子て附加し, 從て雨炭素原子は（III）に於ける如く何机もオクテッドを形成す る。

所でこの狀態に於て二重結合は正常の狀態に比して“ゆるみ”を 生ずる。攻際にX 線的研究の結果によれば二つの炭素間の距離は その間の結合雱子の數によつて次の如く絠する。 
郎ち結合電子の數の減少と共に距離は大きくなる。從て 3 個の結 合電子を有する.上記の風起狀態（II 及び III）に於ては正常牀態 (I) K比して結合のゆるみがあり，從て軸上の趣轉がより自由とな ク，かくして轉位が可能となると推定されるのである。

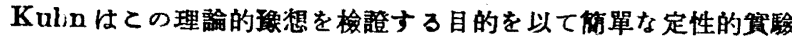
を示してるる。その結果:

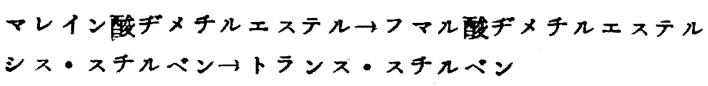

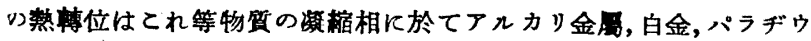
ムの如き常磁性物負によつて明かに促進されるに對し，多くの反磁 性金屓は概して解媒として無教であるてとが知られた。な汪，てれ

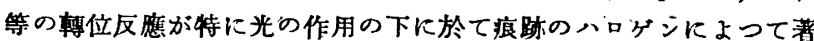
しく促進されるといふ事贯も亦この際光化學的風起飞依て生ずべ ハロゲン原子の常磁性に鯞すへきであると說明されてるる。

かゃ5な見解を更確める篇に筆者は凝縮相に於けるマレイン酸 ヂメチルェステルよりフマル酸デメチルェステルへの轉位に對する $\mathrm{O}_{2}$ 及び NOO影繁，水溶液中下於けるマレイン酸よりフマル酸一 の轉位に對する白金，パラデウム，各種常磁性金属イオンの影繁等 を定量的に检證した結果，肯定的な結果を得た。

以上の貫例は“均一”氣體䚚媒反應の規籍には屬さないるので あるが，筆者は更に氣相中に於りる次の轉位反應：

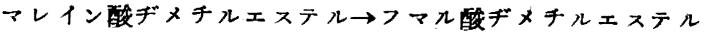

シス・ヂクロルエチレンートランス・ヂクロルエチレン

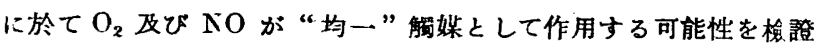
した。その結果には未だ多少の籎點を存してるるが， $\mathrm{O}_{2}$ 及び $\mathrm{NU}$ の常磁性による促進作用は少くとる部分的に示されてるる。

\section{4. 徽量の水分によつて影響される反應}

從來微量の水分郎ち照氣に依て促進されるといふ氣嘈反應が少か らす記载されてるるが, これ等ば一見“均一”氣體触媒反應の如 くに考へられる。しかしての潜氣の影警江關してはその後多くの精 湅な研究によつて必すしも常に再現可能の結果が得られない事が明

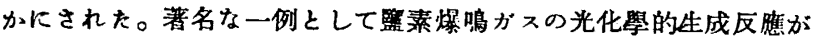
あるが, Coehn 及び共原研究者によると，ての場合反應混合氣能 中に於て水蒸氮の分壓が $10^{-5} \mathrm{mmHg}$ 以下に低下すると，反應は 停止するか，さるなければ僅に 1 光叟子に對して 2 個分子の量子 收量を以て進行するに過を゙ない。しかるにての傎より大すい水蒸氣 橜に於ては 1 光量子に對して $10^{4} \sim 10^{5}$ 分子の量子收量を以て進行 するといふのである。所がこの結論は Bodenstein 飞び Bernreuther 並びに Rol'efson 及び Potts K依て夫々獨立に異なる方法に 依て否定された。郎ち $\mathrm{Cl}_{2}$-爆鳴ガスの反應連鑚は瀑禾の存在に於 ても亦極度の乾嬠狀態に於て子后樣に形成され, 從て何れの場合に る反應は迅速に行はれる事が證明された。Podenstein は Coehn

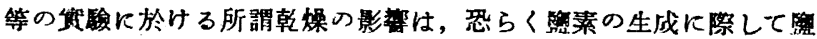
化金更び优の不䢁物が反應空間に紛れ达んだ爲に，てれ等が反應連

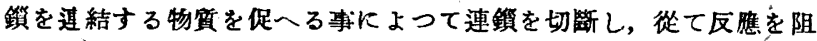
止した事と混后されたるのであららと解說してるる。筫際かやらに 倔然的な原因依て或反應が影警されるとい子事は稀ではないので ある。

Fodenstein は更に所請“乾嬠数果”が主㜊されてるる多くの反 㤫を檢討した結果，てれ等が概して“不均一”であるか, 若しく は連鎦的である事を確め得た。反應が不均一となる一つの原因は水 蒸氣が器㷱の活性部分に吸着される事に依て種々の影繁を及ほす事 に存する。或は又水滴の生成によつて均一空間に於て起り難いゃら な反應が却て誘發されらる事になる第である。例一ば氣相中に於け

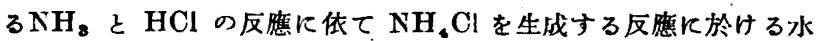
蒸氣の影繁はこのやらな機作に於て起ると想像される。尤るての聞 題にはな㩆點が残されててるる。

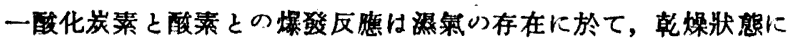

於けるより一層容易に起るてとが知られ，Dixon“はこれを㰠の反 礁例によつて說明した：

$$
\begin{aligned}
& \mathrm{CO}+\mathrm{H}_{2} \mathrm{O}=\mathrm{CO}_{2}+\mathrm{H}_{2} \\
& 2 \mathrm{H}_{2}+\mathrm{O}_{2}=2 \mathrm{H}_{2} \mathrm{O}
\end{aligned}
$$

郎ち $\mathrm{H}_{2} \mathrm{O}$ の存在に依て酸化が間接的に行はれ，乙の間接的酸化 が CO の直接的酸化に比してょり容易に行はれるといふのである。 しかし今日の見解では直接的酸化す間接的酸化と问漛に可能である 事が認められておる。そして何れの場合も反應は連鑟的に行はれる のであるが, 水蒸氮の存在に於ては附加的の連鑚過程が可能となる と推論されてるる。

Baker によれば

$$
2 \mathrm{NO}+\mathrm{O}_{2}=2 \mathrm{NO}_{2}
$$

の反隹子强度の乾燥狀態に於て停止するといはれたのであるが, Briner, Bo !enstein 等の研究はこの結諭を肯定してるない。

要するK渠氣の影警に關しては一義的な說明をなす事が無理であ るゃらに思はれる。唯反應に與かる一物質が水蒸氣と反應して $\mathrm{H}$ 原子丈は $\mathrm{OH}$-基の如き活性の生成物をつくり，てれ等によつて通 常の残驗狀況に於ては起り難いやらな反應が誘發される可能性は想 像するととがでさる。

“均一”氣體解媒反應の研究は化學反應機構の研究に於て特別の

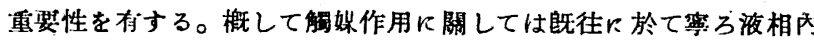

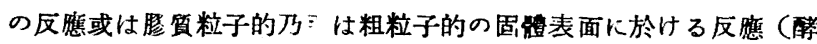

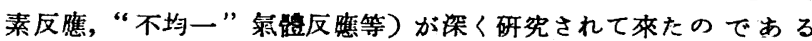
が、これ等の場合は賽際に多くの錯綜した翌素が存在する篇にその

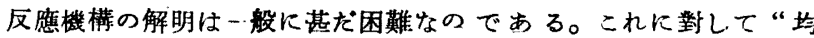

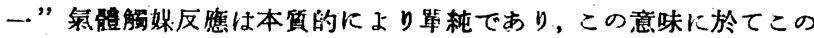
反虑の研究は解㖹作用の本性を究明する目的に對しては一層基本的 なるのと考へられるのである。

さて, “均...”液相触媒反應に於ては，反應㸱質の分子間の街突 數の計算に對して理論的の困難があり，その上溶媒による複雜な影 繁，溶解せるイォンの箖電氣的作用が反應物質の反應活性に對して

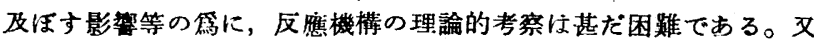
一方，固體表面に於て行はれる觸媒反崤に於ては，“不均一”氣體

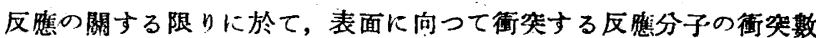
は比較的容易にこれを知る事ができるが，能媒作用の本質的部分が 所調吸着首の中に於て行はれるといふ事の篇に事情は依然として甚 だ袘雜である。吸摜現象に關しては從來非常に多くの研究が篇され て居り，近時に於ては更に，不均二解媒作用之深い關保があると推 定されてるるところの所謂活性吸着の現象飞就ても，多くの研究が 第されてるるに拘らす，觸媒作用の法則性に對する我々の知識は表 面の微䄳槥造々相俟つて未だ滿足なるのではない。

これに對して“均一”氣體触媒反㗹は理論的取扱ひに於て俆程 有利な立場にある。反應物質分子々解媒物質分子之の衙笑數は策體 論によって計算され，從て反應の機會に對する適確な知見が得られ ろ。又電媒的或は静電的影䡬に基づく困難はこの場合假令存在して るてす概して見逃しらる程度のものであり, 且又反應個植として互

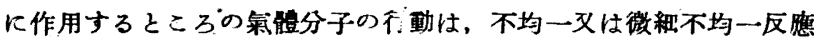
に於ける固體表面の性質に比して遥に究明しやすいるのである。從 て均一氣䱜触媒反應の速度論的研究及びその素子的過程の研究は解 媒作用の本性を探究する上に於て最子基本的のるのと考へられるの である。しかもこの研究は最近に於て濑くその楮についたに過を゙な い狀熊であり，てれК關して今後開發さるでき領域は少くないと思 はれる。

\section{參 考}

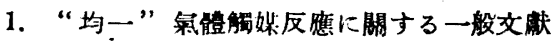

W. Frankenburger, Katalytische Umsetzungen, Leipzig, 1937, 55 
C. N. Hinshelwood, The Kinetics of Chemical Change, Oxford, 1940, 240

H. J. Schumacher, Chemische Gasreaktionen, Dresden, 1938,384

2. 八ロゲンを触媒とする州體反䈍に關する棕括的交獻

H. J. Schumacher, Chemische Gasreaktionen, 388

H. J. Schumacher, Angew. Chemie, 1937, 50, 483

C. N. Hinshelwood, S. Bairstow, J. Chem. Soc. London, 1933, 1147, 1155

S. Bairstow, Trans. Faraday Soc., 1933, 29, 1127

3. パラ，ォルト水素の轉移反應に關する綜括的交獻

A. Farkas, Orthohydrogen, Parahydrogen and Heavy - Hydrogen, Cambridge, (1935)

L. Farkas, Ergeb, exakt. Naturuise, 1933, 12, 163

特に常磁性物質による轉移に關して

L. Farkas, H. Sachsse, Z. physik. Chem., 1933, 23 (B), 1, 19
E. Wigner, Z. physik, Chim., 1933, 23 (B), 28

F. Kalckar, E. Teller, Proc. Roy. Soc. London, 1935, 150 (A), 520

H. Sachsse, Z. Elektrochem., 1934, 40, 531

4. エチレン化合物のシス・トランス轉位に關して

R. Kuhn, Stereochemie, herausg. vón K.Freudenberg, Leipzig, 1933, 913

B. Tamamushi, H. Akiyama, Z. Elektrochem., 1937, 43, 156; 1939, 45, 72; Bull. Chem. Soc. Japan, 1937, 12, 382 F. R. Mayo, C. Walling, Chemical keviews, 1940, 27, 403

5. 微量水分によつて影響される反應に關して

M. Bodenstein, Z. physik. Chem., 1933, 20 (B), 451

W. Frankenburger, Katalytische Umsetzungen, 66

C. N. Hinshelwood, The Kinetics of Chemical Change, 245

J. W. Smith, The Effects of Moisture on Chemical and Physical Changes, New York, (1929)

\section{新 刊 巢 報}

日本化量合誌 第 62 帙第 5 號 (昭和 16 年 5 月)

カーバイド電氣爐內に於ける不純物の狀態

飞び分布に就て

カーバイド生成に於ける Material Balance に就て

毒 野 武 雄

清 野武雄

炩虽監の電氣傳導度の研究 (第 3 報)

電解傳導々粘性との關係

裁及び鎆中の燐の定量

熱墴散管を用ふる化學反應の研究

メタンの熱重合反應

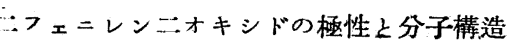

フェノクスチンの極性と分子構造

東 健一.上尾庄次郎

還元銅に依了芳香屬化合物の核內水素添加の研究 (その 3 )

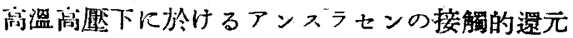

杉野喜一郎・大內謙一

重酸素の利用に依る糖類の化學的性質の研先 (第 2 報)

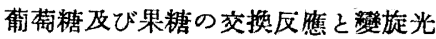

玨草化學成分の研究 (その 5$)^{\circ}$

黃色種凐草精油の含量, 比重, 届折率等福島好郎 - 大池國威

米胚芽の Oestrone 樣物質之醉素合有蛋白質

に就て（第 1 報）

田所哲太郎・成藤恒行

Ascorbin 酸オキシダーゼの化學的性質（第 17 報）

由所哲太郎

東亞に特有なる低形科植物イヌカウジ二屬の精油に關する研究

(第 12 報) オヤイメカウジュ(新稱)の精油藤 田安二

南方産植物精油に關する研究 (第 2 報)

フィリッピン座パピナ油及びタゴグニリット油藤田安二

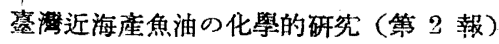

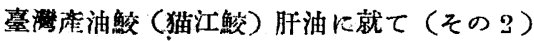

アルコール並に脂肪酸成分

烟忠太・國崎展喜

Nupharidinの構造に關する研先 (豫報)

小竹無二雄・父保田倫志・萩谷 涁

電莱化罗 第 9 卷第 6 號 (昭利 16 年 6 月)

銅の電解製鍊に於ける監素の影準

穴瀷健灭・枮山 兌
電話器用炭素粉に就て

炭素棒の特性々溫度々の關保

釜萢善一・石井賢一 田中 洸・吉田克

醇造缼雜誌 第 19 参第 6 號 (昭和 16 年 6 月)

生化學工業工場廃液の利用に關する研究（第 $1 \sim 2$ 報）

甘藷を原料とする酒精製造工場蒸溜廢液の酵母製造原料

としての利用法

糖蜜を原料とする酒精製造工場蒸溜廢液の酵母製造

原料としての利用法

ヴィタミン $B_{1}$ 資源調查（第 16 報）

ヴィタミン $\mathrm{B}_{1}$ の此色定量法

高田亮本

高田亮本・村上江美

ぞくぐりのタンニン抽出と酸醉に關する研党 (第 2 報)

木幡健五郎·秋吉春雄・阿野藤七

鳳梨罐㯰製造副座物の利用研究(第 2 報)

風梨酶製造試驗

㯺入英次·本田志郎・楊 熙 昌

溶劑に依るフルフロールの抽出に就て 市 野 一 - 路

住友電氣郝 第 21 號 (昭和 16 年 5 .月)

亞鉛鉞金線のアルカリ試驗法に關する考察（第 3 報）

ゴムに對す銅の影響（第 3 報）

橋本誠一・小林 清 大 北 忠 男

科學之工業 第 16 卷第 6 號 (昭和 16 年 6 月)

還元觸 媒安村二郎

ズルフォンアミド劑の發展

久保松照夫

M. J. Kagan 氏依るアセトアルデヒド及び水

よりアセトン生成に關する機潔に就て

ニトロパラフィンに就て

熱可塑性 ゴム狀合成物質 (II)

激枌の化學 (IV)

本邦に於けるフルフラール製造の工業的原料に關す

る檢討

伊 藤 教 勝

F 谷一郎

阿 部忍

柏谷義三郎

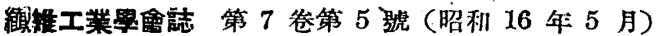

バネを利用する杼投裝置の試作 內田豐作・大澤源一郎・越坂康夫

蔽の乾燥程度加製絲・精練・染色性質に及ほす影響

に就て

美 和 正 忠 